\title{
rommhalina
}

(8)

\section{Mito, memória e crise}

\begin{tabular}{ll} 
Autor(es): & Fialho, Maria do Céu \\
Publicado por: & $\begin{array}{l}\text { Centro de Estudos Clássicos e Humanísticos; Imprensa da Universidade } \\
\text { de Coimbra }\end{array}$ \\
$\begin{array}{l}\text { URL } \\
\text { persistente: }\end{array}$ & URI:http://hdl.handle.net/10316.2/31545 \\
DOI: & DOI:http://dx.doi.org/10.14195/978-989-8281-23-4_4 \\
Accessed : & 26-Apr-2023 14:46:19 \\
\hline
\end{tabular}

A navegação consulta e descarregamento dos títulos inseridos nas Bibliotecas Digitais UC Digitalis, UC Pombalina e UC Impactum, pressupõem a aceitação plena e sem reservas dos Termos e Condições de Uso destas Bibliotecas Digitais, disponíveis em https://digitalis.uc.pt/pt-pt/termos.

Conforme exposto nos referidos Termos e Condições de Uso, o descarregamento de títulos de acesso restrito requer uma licença válida de autorização devendo o utilizador aceder ao(s) documento(s) a partir de um endereço de IP da instituição detentora da supramencionada licença.

Ao utilizador é apenas permitido o descarregamento para uso pessoal, pelo que o emprego do(s) título(s) descarregado(s) para outro fim, designadamente comercial, carece de autorização do respetivo autor ou editor da obra.

Na medida em que todas as obras da UC Digitalis se encontram protegidas pelo Código do Direito de Autor e Direitos Conexos e demais legislação aplicável, toda a cópia, parcial ou total, deste documento, nos casos em que é legalmente admitida, deverá conter ou fazer-se acompanhar por este aviso.

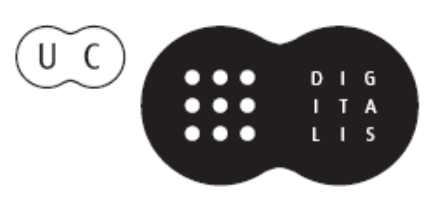


Colecção Autores Gregos e Latinos Série ENSAIOS

\section{Delfim Ferreira Leão José Ribeiro Ferreira Maria do Céu Fialho}

CIDADANIA E PAIDEIA

Na Grécia Antiga 


\title{
Mito, Memória e Crise
}

\author{
Maria do Céu Fialho
}


Sem memória não há princípio de esperança. ${ }^{1}$

Escreveu um dia o filósofo Miguel Baptista Pereira: "Crise sem tradição não tem raízes nem solo, tradição sem crise está morta e consumida”. ${ }^{2}$ Esta reflexão sintetiza, com particular acuidade, o conflito entre o contemporâneo ocidental e a tradição em que mergulha as suas raízes e à qual deve o substancial do seu legado identitário.

Diversos e diversificados foram os tempos de crise que o Ocidente, especificamente a Europa, conheceram ao longo da sua história - se acaso não são de 'crise' todas as épocas, já que a consciência histórica implica a avaliação de valores e do sentido do acontecer. Mas há que reconhecer que é particularmente radical a crise de uma contemporaneidade, agravada pela crise económica mundial, pelo esbater de identidades, decorrente de uma globalização que mais obedece a interesses de grandes potentados económicos que a ideais de igualitários, a braços com a sua relaçáo com um passado recente por resolver.

A face que a Europa viu de si mesma, logo após a Segunda Guerra Mundial, empurrou-a para além do que consideraria os limites possíveis da sua capacidade

${ }^{1}$ Miguel Baptista Pereira, (1993) 453.

2 (1995b) 217. 
de falta, tornando ineficaz o processo de construção, por fraqueza, de uma imagem de humanidade e de dimensão paradigmática de um humanismo muitas vezes decorrente da abstracçáo e esquecimento de culpas. A realidade dos campos de concentração estava aí, mais ainda que nos relatos, nas imagens. E ela aproximou e aproxima vencidos e vencedores, no horror que os envolveu e potencialmente é capaz de envolver, ainda que de modos totalmente diversos - já que todos (vítimas e carrascos) pertencem a uma mesma Humanidade, capaz de tais horrores. Não se tratou, alguns anos depois, quando a visão da dimensão dos factos se tornou mais clara, de apurar de que lado morava a culpa, pois o mal e o morticínio gratuito, em nome de uma loucura que arrastou multidóes, a todos diz respeito («tua res agitur») - como o mythos de uma tragédia representada no teatro. Ninguém ficou a coberto da inocência.

Até que ponto se arrastou o que Hannah Arendt designa por "banalização do mal" fica bem claro no seu relato do julgamento de Eichmann em Eichmann em Jerusalém. A superfluidade do humano esvaziou a vida de assassinos e assassinados, esvaziando-os e esvaziando o próprio contexto da cultura em que nasceram. ${ }^{3}$

Subsequentemente, foi ganhando força a resistência e a afirmação de autonomia das colónias, que levou ao esboroar de impérios e ao nascimento de novas naçóes, em outros continentes, por vezes após duras experiências de guerra. As nações europeias

${ }^{3}$ Pode consultar-se, sobre este livro, o comentário feito em: http://xooner.alice.it/direitousp/curso/arendts.htm 
encontraram-se, então, a braços com a dificuldade em se auto-reconhecer no seu espaço originário, a par da mescla e de atropelos de identidades e tradiçóes de povos, impostos pelo 'lápis azul' de Staline após a repartição do espaço europeu em esferas de influência dos países aliados no após-guerra - atropelos que geraram novos conflitos, migraçôes, genocídio, perseguiçôes religiosas, num passado recentíssimo.

O olhar de espanto, de onde surgiu a Filosofia Grega, converte-se em olhar perplexo, perante uma Europa esvaziada de referências, a braços com a culpa, atordoada por um futuro que náo vislumbra na falta de sentido para o presente - esquecer, não é possível, impóese a memória dos actos - como um sinal de aviso, como a voz da vítima, a memória de uma desmesura possível que há que não repetir. De onde pode brotar o dom do perdão, que não leve o homem a fugir de si mesmo, mas a reconciliar-se criticamente consigo, com o seu chão e a assumir as suas raízes como fonte ainda revigoradora de diálogo e marca referencial?

A fuga da Europa de si mesma e o discurso do pós-colonial, raízes cortadas com a síntese primordial e sempre inspiradora greco-romana e judaico-cristá, surge como uma alternativa repetida na boca dos que se afirmam “pós-modernos”. O diálogo é, de facto, preciso, mas não quando transporta com ele velhos complexos por resolver. O diálogo é possível, quando se não abdica da identidade assumida.

E a identidade assumida carece daquela ancestral tradição helénica da reflexão filosófica sobre a pólis, esse 
olhar teórico, que implica distanciamento crítico, mais do que da imediata materialização do pensamento político confundido com a acção política. Esta é necessária, mas náo deve ser confundida com o olhar teórico, sob pena de se cair no imediatismo da intervenção sem projecto fundador. Este é, por natureza própria, enquanto fundador e enquanto projecto, produto da reflexão compreensiva da articulação tradição/passado/memória no seio da qual nascemos - o nosso 'fundamento'- que nos abre para uma leitura de mundo e aposta no futuro a partir do que somos, convertendo esse património em potencial capaz de gerar esperança. O olhar teórico e a intervenção prática não são confundíveis, nem coincidíveis. E a contemporaneidade, sobretudo desde finais do séc. XIX, desvalorizou a diferença e esqueceu-a. ${ }^{4}$

Este é, por outro lado, o tempo das contradiçóes: do discurso, algo estafante, do diálogo intercultural, a par das vagas de intolerância e fanatismo, de nacionalismos agressivos. A razão crítica apregoa a tolerância, deu abertura à dessacralização da Natureza, dominada pelo Homem. 'Penso, logo existo', como verdade cartesiana, inaugurou o tempo do sujeito dominador do mundo e sancionou um futuro que não podia imaginar - o da tecnocracia, pensada como libertação e tornada escravizadora. A filosofia do trabalho para produzir e do produzir para consumir, indissociável do ideal de sociedades da abundância, criou um ciclo em que a massificação superficializou o Homem que, escravo do consumo, numa confusão eufórica entre ter e ser,

${ }^{4}$ Veja-se ARendt (2006). 
esventra a Natureza em busca de matéria-prima, altera-a em função do 'conforto' e do lazer programado. A Natureza desventrada vinga-se. A tolerância convive com o mais radical fundamentalismo.

Que laços nos ligam, ainda, às nossas raízes culturais?

Reconhecê-las não basta. Reproduzi-las ou a elas se ater, num revivalismo passadista e escapista significa extirpá-las de sentido. "Tradição sem crise está morta e enterrada”.

A tradição (conceito e palavra herdados de Roma) como lastro do passado náo oferece abertura de sentido para o futuro, nem raízes em que nos reconheçamos, neste constante entrelaçar entre passado e futuro. Quanto a este esvaziamento, Hannah Arendt aponta o dedo para a crise de autoridade nos padróes de ideais educativos que vingaram a partir dos anos cinquenta do século passado no Ocidente, por influência de correntes psicopedagógicas de matriz americana. Auctoritas significa, em Latim, 'autoridade', 'influência', 'prestígio', 'conselho', 'impulso'. O termo é cognato de auctor, 'o que aumenta a confiança', 'o garante', 'o mestre'. Fazer crescer para a criatividade, para a inovação, significa, precisamente, transmitir o testemunho de um passado e do sentido da tradiçáo, ainda que seja para que o educando o ponha em causa, no seu processo de crescimento. Mas é no seio do passado que se nasce e se aprende linguagem. Privar quem nasce deste património constitui uma opção de empobrecimento e errância. 
A 'crise' da tradição, no sentido de um diálogo crítico com as matrizes culturais, implicará, então, a partir da contemporaneidade, a reflexão sobre o que nos vem do nosso berço cultural, o que configurou o que somos e, mais ainda, o que se perdeu e subverteu desse universo cultural dos primórdios (sobre a relação com a Natureza ou, melhor, sobre a nossa humilde pertença à Natureza, como "partículas pensantes do universo» muito haveria a dizer, acompanhando os PréSocráticos), o que dele herdámos em que estivesse já contida a semente de cisóes e erros do que somos hoje.

Antes do 'penso, logo existo' da minha racionalidade existia o universo-casa dos afectos que me geraram e a harmonia de uma Natureza como grande texto, inesgotável, íntegro, que me acolhe como seu (por isso me convida a respeitá-la enquanto texto que se me oferece).

Reflictamos, por exemplo, sobre uma experiência que nos é familiar: a da memória da infância de todos nós, ou o que dela julgamos ter: ela contém as marcas referenciais das primeiras narrativas escutadas, numa envolvência de afecto, a que não está alheia uma dimensão de ritualização de um acto e gesto repetidos, tão próprios do gosto da criança. Em tais narrativas se cristalizam situaçóes exemplares que cumprem uma oculta pedagogia pelo fascínio dos ouvidos atentos. Nelas se abre um imaginário partilhado por geraçóes sucessivas, como elo de um património comum.

A memória dessa mesma infância, por seu turno, 
articula-a o homem numa narrativa de origens que conhece um largo espaço na própria ficção romanesca e que nessa mesma ficção romanesca é assumida como projecção da disposiçáo emotiva do presente, da idealização de origens, numa infância afinal nunca recuperável, mas ordenada, na memória, a partir da temporalidade do que ainda há-de ser na história do indivíduo. Tal consciência está presente e abre portas à reflexão no contexto romanesco da obra de Natalie Sarraute, cuja influência marcará, determinantemente, o discurso das memórias de ficção.

Tomando mythos no seu sentido original de 'narrativa', consoante o faz Paul Ricoeur, numa obra como Temps et Récit, ${ }^{5}$ sou levada às seguintes perguntas: que faz do homem um construtor de mitos? que realiza o homem nos mitos que, desde a infância, o acompanham e nesses mitos que constrói - incluindo o das suas próprias origens - na sua existência de indivíduo ou no contexto de uma cultura colectiva? que perde o homem, em contrapartida, despojado de mitos e da comunicação por eles?

Escutemos Vergílio Ferreira, em palavras postas na boca de um dos seus narradores — a de Alberto Soares em Aparição —, sobre a infância narrativizada pela memória: ${ }^{6}$

A alegria que procuro é de um outrora absoluto, desde antes da infância, desde o eco que me transcende do passado ao futuro.

${ }^{5}$ Vols.I-II-III (1983-1985).

${ }^{6}\left(1996^{30}\right)$ 135. Cf. Fialho (1997) 203-217. 
É que o passado evocado, em narrativa articulada, constitui o presente que nunca foi, conforme o reconhece o autor em Invocação ao meu corpo. ${ }^{7}$ Isto é, na narrativa poetizada de si mesmo - e poetizada porque opera, a partir de factos evocados, uma abertura para um imaginário de projecção - o homem a si mesmo se procura e tenta compreender. ${ }^{8}$

Consoante o confessa, exemplarmente, o escritor, ainda em outros contextos, move-o a procura, não do factual, mas de um universal que toca a experiência temporal condensada na narrativa: experiência que é a do tempo presente, vivido em mundo e em situação, num instante que deixa pressentir o imutável e que instiga o criador da narrativa a captá-lo. É nesse eterno desassossego, de tentar compreender-se e de tentar compreender essa intersecção em que existe, entre transitório e permanente, que reside o verdadeiro móbil do mythos: ${ }^{9}$

As histórias que nos contamos não são, pois, um meio de nela revermos a nossa vida, mas um desesperado esforço para que nos possamos rever.

7 "Do passado e do futuro" (1969) 105.

${ }^{8}$ Nos seus ensaios, Vergílio Ferreira fala frequentemente da sua escrita e do acto de escrever como tentativa de captar, no mito que tece, o mistério da vivência humana do tempo e que o transcende. Em "Eu e o presente" (1969), 83-96, evoca S. Agostinho e o reconhecimento, por parte do filósofo, na esteira de Cícero, De natura deorum, de que a vivência do tempo é própria do homem, da sua natureza e finitude. Veja-se a obra de Laso (1989) 71 e 82 sqq.

9 "O mito e a sua mitificação" (1969) 46. 
Não são a sintese de uma constatação, mas uma forma de podermos constatar.

Ainda na poetização narrativa da memória, conscientemente assumida na ficção vergiliana, percebemos a acuidade da constatação aristotélica: a Poesia diz o que pode acontecer, a História fala dos factos. Por isso a primeira é mais filosófica que a segunda, isto é, o discurso poético toca o universal, o da História o particular.

Assumido o espaço de abertura entre o que foi de nós, e constitui experiência temporal não recuperável, e a sua reconfiguração poética a partir do estar-nomundo presente, determinado por todas as nossas vivências, pela nossa história e pela nossa linguagem, aí, a partir desse espaço de abertura, procura o homem tocar o universal de si mesmo, imbricado no paradoxo da sua finitude. Assume-o ainda Vergílio Ferreira, em palavras pronunciadas aquando da sua investidura como doutor honoris causa pela Universidade de Coimbra, no contexto de um ritual universitário que aviva, na festa, a centenária tradição de uma comunidade que transcende o presente e revivifica o seu sentido na consciência das raízes da tradição — gesto que traduz e reafirma, ao mesmo tempo, a esperança no futuro: ${ }^{10}$

O passado a que pudéssemos voltar com uma "máquina do tempo" seria a decepção do presente

${ }^{10}(1994)$ 508-511. 
que foi e o imaginário nos transfigurou. Ora é esse imaginário que me perdura da Coimbra que foi minha. Mas não tendo existido, configura o grande mito que me existe da minha juventude. Entremeado assim ou insinuado assim à distinção que a minha universidade magnanimamente me quis conferir, é esse mito que se me desdobra como diadema do mais. O passado que se evoca nunca existiu para ninguém. Mas só o que não existe é que é bastante para o excesso do homem. Assim o real da minha juventude é o transreal do seu encantamento e da eternidade que lá mora, como nos meus livros o pude registar.

$\mathrm{O}$ cariz e a importância de que se revestem as memórias de origem na existência humana convertidas em objecto de reflexão dentro do próprio discurso ficcional contemporâneo — permitem uma melhor compreensão da natureza e da importância que assume, para uma comunidade, a memória da sua cultura matricial. Inscrita num plano aberto ao imaginário, ela tem a força de um apelo à procura, por parte da comunidade, da marca original da sua própria identidade.

Também esta procura tende a projectar, sobre a arche cultural, à imagem do que ocorre com o indivíduo, o desassossego da busca e compreensão de si mesma de uma cultura que procura validar-se na absolutização de memórias, na origem idealizada e mitificada.

Será igualmente válido, no plano do colectivo, na evocação do passado que fundamenta a expressão cultural e a consciência de identidade do presente, o que 
o discurso metaficcional de memórias autobiográficas assume: o passado que se evoca é o passado que nunca foi e, no entanto, nesse mito necessário se procura o homem. Nele tenta encontrar o absoluto que o toca a dimensão de perenidade que anima e dá sentido aos valores que articulam uma sociedade e fundamentam a sua natureza, conferindo-lhe especificidade.

Percebe-se, assim, qual a força que levou à idealização da Grécia Antiga. Após o contacto da Europa com a arte grega, nomeadamente com a escultura, sobretudo através de cópias romanas, o séc. XVIII marca a descoberta de originais gregos e o crescente interesse pelo seu conhecimento, o que leva ao empreendimento de viagens à Grécia de arqueólogos e de estudiosos da ciência que entấo nasce, da História da Arte Antiga. Esse é o século de Winckelmann e a sua compreensão da arte grega como expressão estética natural e necessariamente surgida do próprio enquadramento paisagístico e das condiçóes de luminosidade da Grécia hão-de determinar decisivamente o caminho para a idealização da Hélade como arquicultura, mediada pelo idealismo hegeliano e abraçada pelo Romantismo alemão, e que marcará, até aos nossos dias, o imaginário ocidental. A ela devemos, a título de exemplo, os momentos mais altos da inspiração de Hölderlin ou Lord Byron até à poesia de Rilke e aos poetas nossos contemporâneos que a receberam, como, entre nós, Eugénio de Andrade ou Sophia de Mello Breyner. 
A título de exemplo, a Grécia assume, em Sophia, a natureza de um tempo-espaço primordial de plenitude de ser, manifestada pela mediação da própria luz a que se torna visível (e que permite suspeitar da componente tenebrosa também existente). Visitar a Grécia é, assim, sinónimo de peregrinação à marca das origens, mas, mais ainda, a Grécia arquetípica, como modelo e fonte de plenitude, marca todo o espaço que abre para essa vivência, quer pela mediaçáo da luz — a paisagem mediterrânica, aberta ao infinito de um mar de azul intenso, sulcado pelo mito, pelos Gregos e por nós, banhada e revelada pelo sol — , quer pela presença de sinais que actuam como ícones platónicos do modelo. É o caso da ânfora de Arte Poética I que, tomada da penumbra da loja de barros, eco da caverna platónica, é posta pelas mãos da sacerdotisa poética frente ao mar, banhada pelo sol, num ritual de aliança restabelecida.

Todo este gesto de celebração é, aqui, criado pela palavra poética e é o poeta, como verdadeiro xamã do Ser, quem tem o poder de evocaçáo da instância de plenitude fundadora de sentidos e de harmonia. Grécia e Poesia são, afinal, equivalentes em Sophia e os Gregos senhores da consciência plena da condição humana:

\section{OS GREGOS}

Aos deuses supúnhamos uma existência cintilante

Consubstancial ao mar à nuvem ao arvoredo à luz

Neles o longo friso branco das espumas o tremular da vaga A verdura sussurrada e secreta do bosque o oiro erecto do 


\section{$O$ meandro do rio o fogo solene da montanha} E a grande abóbada do ar sonoro e leve e livre Emergiam em consciência que se vê

Sem que se perdesse o um-boda-e festa do primeiro dia Esta existência desejávamos para nós próprios homens Por isso repetiamos os gestos rituais que restabelecem $O$ estar-ser-inteiro inicial das coisas -

Isto nos tornou atentos a todas as formas que a luz do sol [conhece

E também à treva interior por que somos habitados $E$ dentro da qual navega indicivel o brilho

A eloquência do exemplo dado permite-nos perceber como, na linguagem da poesia, tal equivalência assenta na capacidade que a Grécia assumiu de se poder oferecer como metáfora — com toda a abertura que a natureza da metáfora lhe confere — de uma plenitude primordial, dadora de sentido, buscada pelo Ocidente, nos seus espaços de imaginário, através da voz dos seus poetas. Chamemos-lhe Grécia ficcional, mas reconheçamos essa ficcionalização dotada do irrefutável valor cognitivo da metáfora, ${ }^{11}$ assim como Vergílio

${ }^{11} \mathrm{O}$ reconhecimento do poder cognitivo da metáfora remetenos para o próprio princípio metafórico da linguagem no seu poder de alcance para construção de novos conceitos — o que tem sido diversamente valorizado. As origens de uma teoria da metáfora remontam à Poética e Retórica aristotélicas (Poética, 1457b 1-9; 1458a 18 - 1459a 14; Retórica III, 1410 b 12 sqq.), que distinguem o kyrion onoma da metaphora, traduzidos para o latim de Cícero e Quintiliano como verbum proprium e translatio. A percepção desvirtuada que será feita de proprium como 'adequado' tenderá a instalar a tradição da percepção da metáfora como sentido 'figurado', não próprio. VICO recupera e aprofunda a força da metaphora aristotélica, aproximando-a do mito ("cada metáfora ... 
Ferreira e os seus narradores o reconhecem na infânciamito que criam e no que nela se busca.

A capacidade de se constituir em linguagem do inesgotável, que por ela se deixa dizer, confere a esta Grécia-metáfora o estatuto de mito, de acordo com a similaridade observada por Paul Ricoeur entre a valência e função da metáfora e do mythos.

No entanto, ainda na banalização e apropriação consumista deste mito, que o contemporâneo turismo de massas ao espaço grego representa, como tão sabiamente o dilucida N. Himmelmann, ${ }^{12}$ se traduz um dos vazios se sentido das sociedades contemporâneas.

Da Grécia como metáfora, ou do mito da Grécia, a que se reconhece a dimensão de ficcionalização com as suas riquezas e limitaçôes, há que distinguir a Grécia dos mitos, a Grécia como cultura, com identidade e um discurso próprio, que, inscrita no domínio da

torna-se num pequeno mito”), ao converter-se em expressão plástica de realidades não palpáveis. Verifica Vico que, em todas as línguas, é através de um processo metafórico que o vocabulário das artes e ciências se forma e enriquece, a partir de palavras do âmbito rural: apud Bremer (1980) 350-351. Este artigo contém uma valiosa bibliografia sobre Teoria da Metáfora, de que se salienta, para além de Cassirer e de Coseriu, Vonessen (1959), Landmann (1963), Gadamer (1975ㄴ) 406-409, Weinrich (1967), Ricoeur (1975). Veja-se também Pereira (1995a), em especial 6-7: “...Vico, ao recusar o mito como veste alegórica da verdade, reconheceu-lhe uma forma própria de linguagem com que o homem procura superar a sua originária estranheza no mundo e inaugurou uma interpretaçáo do mito retomada mais tarde por E. Cassirer".

${ }^{12}$ (1976). 
alteridade, nos interpela a uma atitude hermenêutica de compreensão e abertura de horizontes, num processo de diálogo intercultural. Esse diálogo assume, no entanto, um cariz muito próprio, já que esse Outro contém, na sua especificidade, a matriz originária que, vindo a conhecer processos de apropriação e síntese, determinou e determina ainda a nossa identidade e muito do nosso modo de apreensão e compreensão do mundo da nossa existência.

O diálogo privilegiado com esse Outro, matriz do Eu cultural, abre caminho à compreensão crítica da nossa identidade e propicia uma inesgotável fonte de reflexão sobre ela. Não se trata de sancionar narcisicamente o que somos, ao revermo-nos nas origens, como num espelho, mas de compreender, além do mais, a razão de ser dos nossos limites, da consonância e da diferença, em relação a esse Outro, na determinação criada por uma linguagem cultural que se foi configurando, na História, e na qual o mundo se nos abre e aprendemos a pensar.

A inesgotabilidade do estímulo desse diálogo reside no facto de a cultura clássica, no caso em apreço a cultura grega, sendo para nós matriz de identidade sem perder a sua natureza de alteridade, nos oferecer, como novas possibilidades de aprofundamento de consciência crítica - e, logo, de capacidade de construção de caminhos para o futuro - o que da origem se perdeu, se esqueceu, se desvirtuou, em apropriaçóes redutoras e pode ser recuperado, numa atitude de abertura hermenêutica. Pensar os Gregos de modo mais grego, consoante a 
proposta heideggeriana, "pensar com os Gregos não é abandonar a nossa situação histórica mas aprofundá-la, em atitude de co-naturalidade e co-genialidade; é uma empresa e um desafio gigantesco, a que não podem corresponder os que obstinadamente seguem a via da mediocridade". ${ }^{13}$

Falei de 'Grécia dos mitos' já que foram os Gregos, desde cedo, os primeiros a tomar consciência da dimensão universal dos seus próprios mitos. Sem ela, ainda que somente implícita na Wirkungsgeschichte do mito, não teria este assumido uma crescente importância que vai do discurso da criação poética até à reflexão teórica que, do Romantismo ${ }^{14}$ aos nossos dias, tem vindo a constituir-se num importante campo da investigaçáo nas Humanidades e nas Ciências Humanas, nomeadamente na Filosofia de matriz hermenêutica, como a de Paul Ricoeur e da sua escola.

O modo de celebração poética da vitória, nas várias modalidades desportivas que os Jogos Pan-helénicos integravam, atesta já, claramente, o recurso ao mythos com a consciência plena, por parte do poeta e, logo, por parte da comunidade, da dimensão de instância fundadora e amplificadora de sentido desse mesmo mythos. A execução do epinício assume uma dimensão cívica, enquadrada

${ }^{13}$ Palavras de M. B. Pereira (1977) XXIV.

${ }^{14}$ Sobre a redescoberta que o Romantismo faz da verdade do mito, com Schleiermacher, que lhe concede lugar na sua Filosofia, e com a Teoria do Mito, em Schelling, "que já na juventude projectara uma Mitologia da Razão, que deveria conciliar o monoteísmo da razão pura com o politeísmo da imaginação criadora”, leiam-se as pp. 32 sqq. da brilhante reflexão hermenêutica de M. B. Pereira (1995a). 
na festa comunitária de reconhecimento das qualidades do atleta, reveladas à luz no confronto agonístico e na vitória. Mas tal reconhecimento visa perpetuar a vitória, associando-a à própria existência e sentido dos Jogos, e associando, assim, implicita ou explicitamente, a pólis de origem do vencedor ao local da vitória.

Os epinícios de Píndaro constituem um eloquente exemplo de recurso ao mito para atingir essa amplificação. No contexto da evocação narrativa das suas odes não abundam elementos informativos da vitória. Estes são propositadamente reduzidos a breves referências, ou ocorrem sugeridos, para deixar que o tempo do mito domine o discurso - mito do herói fundador ou protovencedor dos Jogos, mito do herói tutelar da pólis do vencedor celebrado. Cristalizando o mito aquela experiência humana que a sentença (gnome) enuncia como validade universal, ele acolhe o particular da vitória nessa universalidade em que se inscreve o sentido dos próprios Jogos, renovado e actuante em cada competição.

A esse jogo entre particular e universal, que habita a actualização do mito (ainda que ilustrado na leitura do acontecimento histórico que motiva o epinício), foi Aristóteles particularmente sensível nas suas reflexóes sobre a poesia, em particular a poesia dramática, que encontramos condensadas, embora incompletas, nos apontamentos da Poética.

O Estagirita aproxima, em estreita correlação, ${ }^{15}$ dois momentos-chave da composição poética: mythos e

${ }^{15}$ E fá-lo já na apresentação do objecto da sua reflexão (1447a) - a poiesis. 
mimesis, sendo a praxis humana o seu grande unificador. $\mathrm{Na}$ ficcionalidade narrativa, entendida dinamicamente como mimeisthai, ${ }^{16}$ que envolve drama e epopeia, já que estes se distinguem apenas pelas estratégias da mimesis (1448 a 20 sqq.), ${ }^{17}$ articula o poeta a acção humana em nexos que, como observa Ricoeur, condensam e traduzem a sua própria experiência de tempo, não passível de ser expressa de outro modo. ${ }^{18}$

A mimesis consiste nessa operação de representar, pela articulação discursivo-narrativa, os homens em acção (1448 a 1), isto é, o ser-no-mundo do homem, já que todo o Dasein é, por definiçãa, situado e temporal, e toda a temporalidade supóe acção ou sofrimento. Por isso mesmo há que entender que nem mythos nem mimesis são compreensíveis, em Aristóteles, estatica mas dinamicamente.

${ }^{16}$ Observa M. B. Pereira (1993) 441: "Dentro de uma arte poética, mythos e mimesis são operaçôes e não estruturas e, por isso, mythos náo é apenas sistema mas agenciamento dos factos e mimesis é a actividade ou o processo activo de imitar ou representar.

${ }^{17}$ Segundo Aristóteles, a apangelia ou a representação directa dos prattontas kai energountas. M. B. Pereira (1993), 429, chama a atenção para a importância fulcral, para uma releitura compreensiva de Aristóteles, da "operaçáo estratégica de P. Ricoeur" que "eleva a narração a um meta-género, dado o parentesco que o mythos reinstaura entre narração e drama" - o que foi objecto do estudo do filósofo francês. Cf. Ricoeur (1992), 303-320.

${ }^{18}$ Esta questão, no contexto do diálogo hermenêutico de Paul Ricoeur com Gadamer, foi objecto da reflexáo filosófica que constituiu a conferência de M. Luísa Portocarrero, "Mythos aristotélico e poética narrativa em Paul Ricoeur" apresentada no seminário Poéticas: diálogo com Aristóteles, Faculdade de Letras da Universidade de Coimbra, 14 de Fevereiro de 2003. 
O carácter dinâmico de mythos leva a que experiências fundamentais da temporalidade humana se configurem, por transposição, numa narrativa fundadora, etiológica, ou de cristalização de situaçõeslimite — narrativa essa que, a cada actualização, constitui sempre campo de acolhimento de configuração de novas experiências temporais do homem, na sua história. Ele tenta, assim, compreender-se na sua própria criação.

Verifica Aristóteles que mimeisthai (acção substantivada pelo neutro: 1448 b 5) é co-natural ao homem, constitui um symphyton de que extrai prazer. Observa M. Baptista Pereira, no seu diálogo crítico com a Poética aristotélica e a apropriação hermenêutica de Ricoeur:19 "Desenvolve-se no interior da mimesis uma tensão entre a submissão à realidade da acção humana e o trabalho criador, que é a poesia em si mesma, porque o real da referência mimética não é algo cristalizado e inerte, de que só seria possível uma cópia, mas o reino da natureza enquanto fonte dinâmica e criadora, de que só há mimesis quando também se cria. Por isso toda a poiesis é mimética e toda a mimesis é poética”. Daqui resulta que, na percepção aristotélica do nexo profundo entre mimese e acção humana, em contraposição à perspectiva metafísica de Platão, a Poética se aproxima do âmbito da Ética. ${ }^{20}$

Assim lê Ricoeur no seu Temps et récit três níveis de mimese - o do poeta criador, em consonância com a dinâmica poética da própria natureza, o da

19 (1993) 428.

${ }^{20}$ M. B. Pereira (1993) 429. 
mimese no mythos de acçôes humanas, o da apropriação do espectador-ouvinte, de acordo com a abertura determinada pela sua própria temporalidade, sendo o prazer sentido neste último nível o do reconhecimento do que se deixa imitar na ficção narrativa - prazer que assume, na tragédia, a modalidade de catarse. Ora a catarse $^{21}$ decorre do efeito conjugado de duas emoçóes, eleos kai phobos (compaixão e temor), que marcam, utilizando a expressão e conceito ricoeurianos, a mimese III (a projecção/apropriação mimética do espectador em relação à narrativa trágica).

É pela abertura cognitiva viabilizada pela conjugação daquelas duas emoçóes que o homem apreende, na transposição criadora feita para um particular que é a narrativa ficcional, o universal que o toca como possibilidade de acontecer, no tempo único da sua existência de indivíduo, irmanado, contudo, pela sua natureza de homem, com o tecedor de narrativas e com todos aqueles que, consigo, delas se apropriam. ${ }^{22}$

Essa percepção reside, implícita, na diferenciação aristotélica, formulada em Poética, 1451a 36-1451b 7, do discurso poético como mais filosófico (philosophoteron), porque mais universal (diz o ta katholou), ao manter-se no plano da possibilidade do acontecer, em relação ao

${ }^{21}$ Não me detenho na longa discussão que a natureza e efeitos da catarse suscitou durante séculos, nem no contexto cultural que determinou muitas das leituras feitas da catarse aristotélica, por entender que, com isso, me desviaria do objectivo das presentes reflexôes.

${ }^{22}$ Sobre a defesa do carácter universal da mimesis poética, inscrita no contexto da controvérsia com a perspectiva platónica sobre a arte e a poesia, em particular, veja-se López Eire (2001). 
discurso histórico que diz o acontecido (ta genomena) particular (ta kath'hekaston).

Deixemos como observação a latere a nota que Aristóteles não nega de todo ao discurso histórico a dimensão filosófica dada pela universalidade — apenas a considera mais modesta, como há que reconhecer pela utilização do comparativo philosophoteron. ${ }^{23}$

A apropriação da narrativa - tendo Aristóteles dado particular atenção à da narrativa trágica — abre, pois, caminho a um aprofundamento reflexivo da própria experiência de identidade do indivíduo, numa dinâmica hermenêutica que o leva ao alargamento do seu próprio horizonte, ao apreender a universalidade do que, pela mimese, lhe é dito a partir do horizonte do narrador. Em relação à narração da História, observa M. Baptista Pereira que "também as comunidades alcançam a sua identidade mediante narraçóes, que elas mesmas incarnam na sua história efectiva” e que a esta conferem sentido. ${ }^{24}$

Essa percepção é-nos dada, como acima referi, a partir da presença da narrativa de mitos fundadores no momento festivo da celebração cívica dos vencedores nos Jogos, na Hélade, da narrativa dramática ou ditirâmbica dos mitos transmitidos, nos Festivais Dramáticos.

Em cada actualização do mito, hoje, se consolidam os laços de identidade e pertença matricial à comunidade

${ }^{23}$ Sobre a pertinência de uma Filosofia da Poesia, hoje, consolidada pelo diálogo com a Poética aristotélica, veja-se Wieland (2003) 223-247.

24 (1993) 451. Ainda o trabalho de cada historiador não pode ignorar, por crítica, correcçẫo ou ratificação as narraçóes que o precederam, sendo cada escrita da história a procura de um nexo e um sentido na trama dos acontecimentos. 
que, desde a Grécia, o actualizou, como criação e apropriação.

Falo, pois, de um inalienável meio onde se consolidam identidades - também de um "lugar de memória”, na linguagem, com a função integradora que todos os lugares de memória possuem. E memória cultural não significa passadismo — há nela, como reconhece F. Catroga, uma profunda força projectiva; por ela se opera "uma operação de resgate". ${ }^{25}$ Sem linguagem — sem linguagem cultural — não há instrumentos operativos que nos permitam investir na aposta de um futuro que já é, na esperança que dele temos no presente, ou que nunca será, naquilo que da nossa identidade essencial quisermos negar.

Éa memória - especificamente a memória culturalque possui essa capacidade dinâmica de integrar o instante no todo da vida humana e da vida da comunidade. Ela é dadora de sentido. Já Aristóteles o havia compreendido e sugerido, no séc. IV a.C., num tempo de mudanças, em que o Estagirita reflecte sobre a experiência do homem na sua vida em comunidade e no sentido dessa vida, no contexto para que está vocacionada. Lembra E. Lledó: ${ }^{26}$ "Al comienzo de la Metafísica (980b 28-29), Aristóteles afirma que "por médio de la memoria se engendra la experiencia en los hombres»..." E a experiência é o tempo, na sua globalidade, que a confere (Ética a Nicómaco, 1142a 13 sqq.).

25 (2001) 31.

${ }^{26}$ Camps (1987) 137. 
Não se trata de 'utopizar' o passado, mas sim de o considerar como conditio sine qua non para uma abertura de esperança ao futuro, sabendo quem somos, seres com memória cultural e memória de limites, atentos a evitar a fuga a todos os "pós-» que convidem ao esquecimento e ao branqueamento de culpas e complexos.

Que perde, então, o homem despojado de mitos, para retomar a pergunta deixada em aberto? As amarras da sua identidade, para apostar na errância de um ser dotado de bavardage, mas não de linguagem, náufrago de uma "jangada de pedra”, sem rumo nem destino. 


\section{Bibliografia}

Arendt, Hannah: Entre o Passado e o Futuro (Lisboa, 2006, trad. port. J. M. Silva).

Bremer, D.: "Aristoteles, Empedokles und die Erkenntnisleistung der Metapher", Poetica 12 (1980) 350-351.

Catroga, Fernando: Memória, História e historiografia (Coimbra, 2001).

Ferreira, Vergílio: Aparição (Lisboa, 199630).

__ Invocação ao meu corpo (Lisboa, 1969).

—_Alocução de Vergílio Ferreira. Doutoramento solene de Gladstone Chaves de Melo e Vergílio Ferreira", Biblos 70 (1994) 508-511.

Fialho, Maria do Céu: "A infância-mito em Vergílio Ferreira ou a nostalgia da arche”, Confluências 15 (1997) 203-217.

Gadamer, H. G.: Wahrheit und Methode (Tuebingen, $\left.1975^{4}\right)$.

Himmelmann, N.: Utopische Vergangenheit. Archäologie und moderne Kultur (Berlin, 1976).

Landmann, M.: Die absolute Dichtung (Stuttgart, 1963).

Laso, J. L. Gavilanes: Vergílio Ferreira. Espaço simbólico 
e metafísico (Lisboa, 1989).

LLEDó, E.: "Aristóteles y la ética de la "polis»" in CAMPS, V. (ed), Historia de la ética, vol I (Barcelona 1987) 136-207.

López Eire, Antonio: "Reflexiones sobre la Poética de Aristóteles”, Humanitas 53 (2001) 183-216.

Pereira, Miguel Baptista: "Prefácio" à tradução de F. E. Peters, Termos filosóficos gregos (Lisboa, 1977), VII-XXV.

_- "Narração e transcendência”, Humanitas, 45 (1993) 393-476.

_ “O regresso do mito no diálogo entre E. Cassirer e M. Heidegger”, Revista Filosófica de Coimbra, 7 (1995a) 3-66.

—_Revista Filosófica de Coimbra "A crise do mundo da vida no universo mediático contemporâneo", Revista Filosófica de Coimbra, 8 (1995b) 217281.

Ricoeur, Paul: La métaphore vive (Paris, 1975).

__ Temps et récit. Vols.I-II-III (Paris, 1983-1985).

_- "Une reprise de la Poétique d'Aristote", in P. Ricoeur et alii, Nos Grecs et leurs modernes. Les Structures contemporaines d'appropriation de l'Antiquité (Paris, 1992), 303-320.

Vonessen, F.: “Die ontologische Struktur der Metapher, 
Zeitschr. F. philosophische Forschung 13 (1959) 397-418.

Weinrich, H.: “Semantik der Metapher”, Folia Linguistica 1 (1967) 3-17.

Wieland, W.: "Poietische Philosophie und Philosophie der Kunst: Schritte zu einer Philosophie der Poiesis" in: Kann man heute noch etwas anfangen mit Aristoteles?, in T. Buchheim, H. Flashar (Hrsg.) (Darmstadt, 2003), 223-247. 